\title{
Redox control on chromium isotope behaviour in silicate melts
}

\author{
PIERRE BONNAND ${ }^{1}$, EMILIE BRUAND ${ }^{2}$, ANDREW \\ MATZEN $^{3}$, MATTHEW JERRAM ${ }^{4}$, BERNARD J WOOD ${ }^{5}$, \\ MAUD BOYET $^{6}$ AND ALEX N HALLIDAY ${ }^{4}$ \\ ${ }^{1}$ Laboratoire Magmas et Volcans, Université Clermont-Auvergne \\ ${ }^{2}$ Laboratoire Magmas et Volcans \\ ${ }^{3}$ University of Oxford \\ ${ }^{4}$ Columbia University \\ ${ }^{5}$ Earth Sciences, University of Oxford \\ ${ }^{6}$ Université Clermont Auvergne \\ Presenting Author: pierre.bonnand@uca.fr
}

Transition metal isotopes are particularly useful for understanding the conditions under which magmatic processes occur. Moreover, those with more than one oxidation state (e.g. $\mathrm{Cr}^{2+}, \mathrm{Cr}^{3+}$ and $\mathrm{Cr}^{6+}$ ) may also provide powerful constraints on the evolution of the redox state of the mantle. By investigating the $\mathrm{Cr}$ isotopic compositions in both magnesiochromite and silicate melts during experiments performed at $1300{ }^{\circ} \mathrm{C}$ and under controlled redox conditions $\left(-12<\log f \mathrm{O}_{2}<-4\right)$, this study presents the first experimental petro-isotopic investigation of $\mathrm{Cr}$ isotope fractionation and reveals clear systematics between $\mathrm{Cr}$ concentration, isotopic compositions and $f_{2}$. Two series of experiments were performed to study (a) the dissolution of a natural magnesiochromite into $\mathrm{Cr}$-free silicate melts (series A) and (ii) the crystallisation of magnesiochromite from $\mathrm{Cr}$-doped silicate melts (series B). In agreement with previous studies, the $\mathrm{Cr}$ solubility in the silicate melts at equilibrium with magnesiochromite is strongly controlled by oxygen fugacity. Melts produced at low $\mathrm{fO}_{2}$ are enriched in $\mathrm{Cr}$ compared to more oxidised melts. In series A experiments, the $\mathrm{Cr}$ isotopic composition of silicate melts are lighter than the initial chromite starting material. The experiments, performed under reduced conditions, reveal that $\mathrm{Cr}$ isotopic compositions of the silicate melts are correlated with $f \mathrm{O}_{2}$. This demonstrates that, as for the $\mathrm{Cr}$ solubility, $\mathrm{Cr}$ isotopes are sensitive to $\mathrm{fO}_{2}$ and could be used to track changes in redox conditions in high-temperature processes. Furthermore, the $\mathrm{Cr}$ isotopic compositions of silicate melts that are reacted under more oxidising conditions are much lighter than those of melts equilibrated with magnesiochromite at lower oxygen fugacity. The observed variations can be explained by changes in bonding environment for $\mathrm{Cr}$ under oxidised conditions in the silicate melts and/or in the magnesiochromite grains. Similarly, the second set of experiments designed to study fractional crystallisation (series B) suggest that $\mathrm{Cr}$ isotope fractionation is larger under oxidising conditions. 